\title{
Structure of Iron-Nickel Coatings Obtained by Using Pulse Current
}

\author{
Dnipro National University of Railway Transport named after Academician V. Lazaryan, Acad. V. Lazaryan st., 2 \\ 49010 Dnipro,Ukraine, art_vv@ukr.net
}

\begin{abstract}
The paper presents the research results concerning the structure of iron-nickel alloy films obtained with pulse unipolar current from an electrolyte solution. It is shown that under the conditions of unsteady electrocrystallization there are processes on the cathode that lead to the formation of highly nonequilibrium structures and the change in the growth nature of the coating from columnar to layer-by-layer one.

Keywords: non-stationary electrolysis, cathode overvoltage, layer growth, density of dislocations, blocks of
\end{abstract} mosaic.

Article acted received 23.02.2019; accepted for publication 15.03.2019.

\section{Introduction}

The development of modern technology, especially high technology, creates the need for elaboration of materials and coatings with improved physico-chemical properties. The solution to this problem has led to the creation of various methods for the production and application of metal coatings, such as: vacuum sputtering, cathode sputtering, ion-plasma sputtering, chemical deposition, etc. One of the most technologically simple and cost-effective methods is electrodeposition. Practice has shown that the most effective method for obtaining electrolytic coatings in comparison with direct current sputtering is the use of pulse current [1], which is characterized by such parameters as frequency, duty rate and shape of impulses.

The control of these parameters in the process of electrocrystallization can influence the structure of the coatings formed, which makes it possible to significantly expand the spectrum of properties of alloys compared to the alloys obtained using direct current, or significantly improve the existing ones.

In the process of unsteady electrocrystallization, the formation of non-equilibrium and metastable structures is possible; they are similar to those that arise as a result of quenching of alloys from a liquid state $[2,3]$. These metastable structures include the amorphous structure. Alloys with such a structure represent a new class of industrial materials intended for use in modern technology devices.

\section{Experimental technique}

For the production of iron-nickel films, we used a sulfate electrolyte that had the following composition $(\mathrm{g} / \mathrm{l}): \mathrm{NiSO}_{4} \cdot 7 \mathrm{H}_{2} \mathrm{O}-180, \mathrm{FeSO}_{4} \cdot 7 \mathrm{H}_{2} \mathrm{O}-60, \mathrm{H}_{3} \mathrm{BO}_{3}-8$, $\mathrm{NaCl}-8, \mathrm{pH}=3-3.5$. The correction of acidity was carried out by adding $5 \%$ solution of sulfuric acid. The deposition was carried out at a temperature of 293 $298 \mathrm{~K}$ by rectangular current pulses with a frequency of $30-1000 \mathrm{~Hz}$ and a duty rate from 2 to 32 with a constant average current density $\mathrm{j}_{\mathrm{av}}=1.5 \mathrm{~A} / \mathrm{md}^{2}$. The registration of the time dependences of the pulse current and the electrode potential was carried out using a two-beam oscilloscope C1-68 in the electrochemical cell YCE-2. The thin structure of the films was determined on an $\mathrm{X}$ ray diffractometer DRON-3 in monochromatic Co $K_{\alpha}$ radiation.

The alloy microstructure was investigated with the metallographic method using optical microscopes "MIM8" and electron microscopy using scanning-electron microscopes "REMMA 102-2", "JSM-35" and transmission electron microscope "EMV-100L".

\section{Results and discussion}

One of the conditions for the emergence and growth of film coatings from a liquid or gaseous phase is the creation of non-equilibrium conditions at the crystalline phase - liquid (gas) interface. A measure of nonequilibrium for such conditions can be 
supersaturation. The magnitude and time variation rate of which will affect the size and speed of the emergence of new phase nuclei, and accordingly the structure and morphology of the surface in the resulting films.

In the case of electrochemical separation of metals and alloys from electrolyte solutions, cathode overvoltage can act as supersaturation $-\eta(\mathrm{V})$, which can be numerically defined as the difference between the values of the current $(E)$ and equilibrium $\left(E_{0}\right)$ cathode potentials (

The connection between supersaturation and overvoltage on the cathode [4] has the following form:

$$
S=\frac{z F}{R T} \eta
$$

where $z$ - valency of deposited metal; $F$ - Faraday constant.

From this relationship, it can be seen that with the growth of overvoltage, and, consequently, supersaturation, the non-equilibrium of the crystallization process increases; it will rise proportionally to the shortening of time for the cathode potential maximum deviation from its equilibrium value.

The use of pulse unipolar current in the crystallization process at a fixed average density $j_{a v}$ allows to obtain high amplitude (instantaneous) current densities at the impulse moment, by reducing the pulse duration and increasing the pause time. Due to the very little time for the charge to flow through the electrolyte, this leads to the fact that the discharge of metal ions proceeds at more negative values of the cathode potential, in comparison with the conditions of stationary electrolysis. During the current pause, depending on its duration, there is a complete or partial alignment of the ion concentrations in the cathodic region due to their movement from the electrolyte volume. The shorter the impulse, the closer the diffusion front to the surface of the cathode, and the faster the alignment of the concentration of discharging ions.

From the time-overvoltage dependencies on the cathode (Fig. 1-3), it can be seen that with increasing frequency and decreasing pulse current duty rate, overvoltage ripple dies out and the electrocrystallization process becomes similar to stationary.

The higher the supersaturation, the smaller the nucleating centers at a faster rate arise on the cathode at the impulse moment. The relationship between the magnitude of the overvoltage and the size of the crystal nucleus arising [5] is as follows:

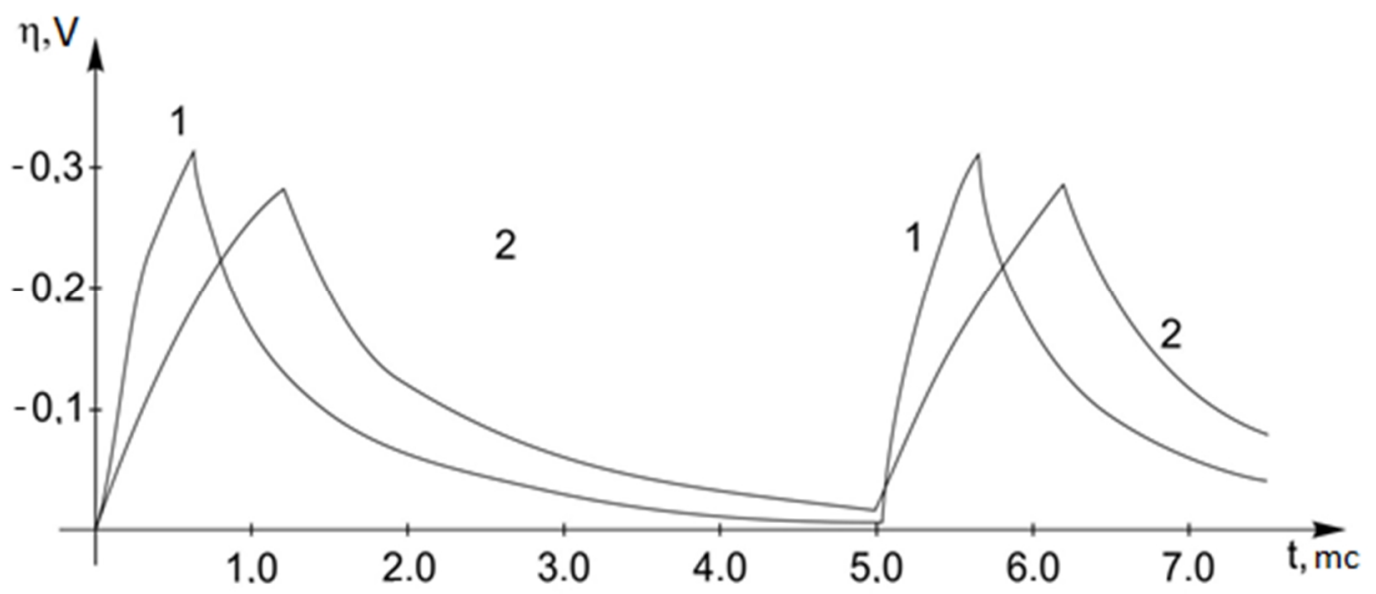

Fig. 1. Overvoltage change on the cathode during the pulse current period: $1-f=200 \mathrm{~Hz}, \mathrm{Q}=8 ; 2-f=200 \mathrm{~Hz}, \mathrm{Q}=4$.

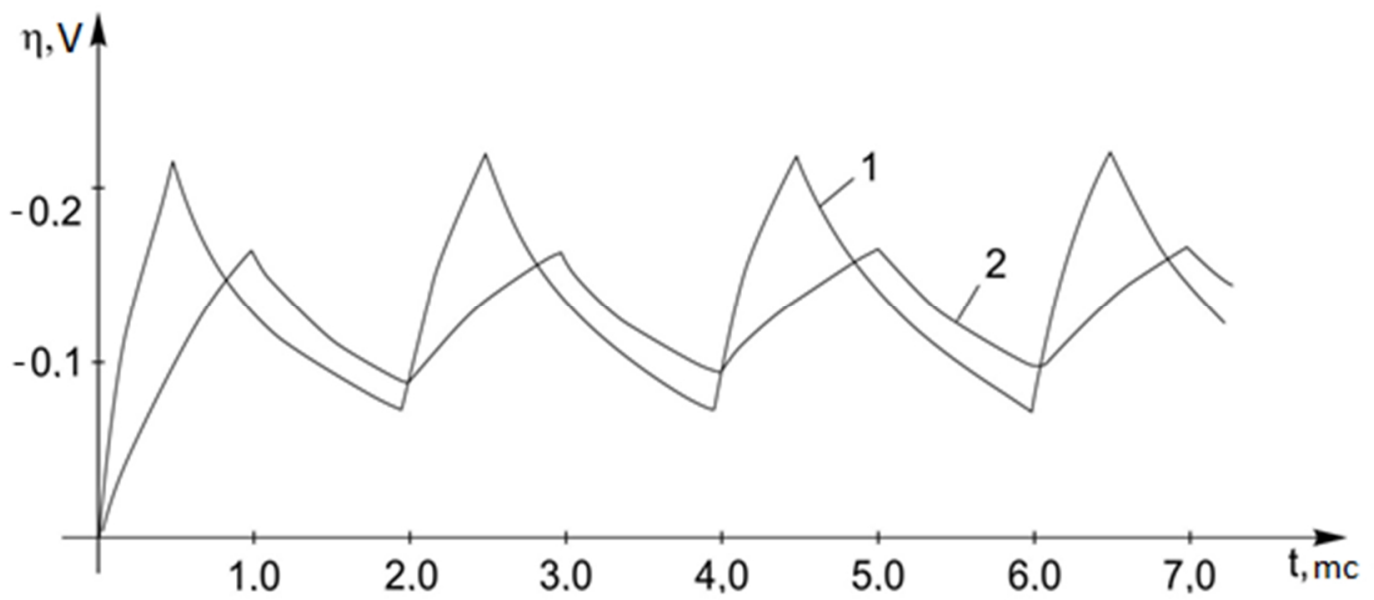

Fig. 2. Overvoltage change on the cathode during the pulse current period: $1-f=500 \mathrm{~Hz}, \mathrm{Q}=4 ; 2-f=500 \mathrm{~Hz}, \mathrm{Q}=2$. 


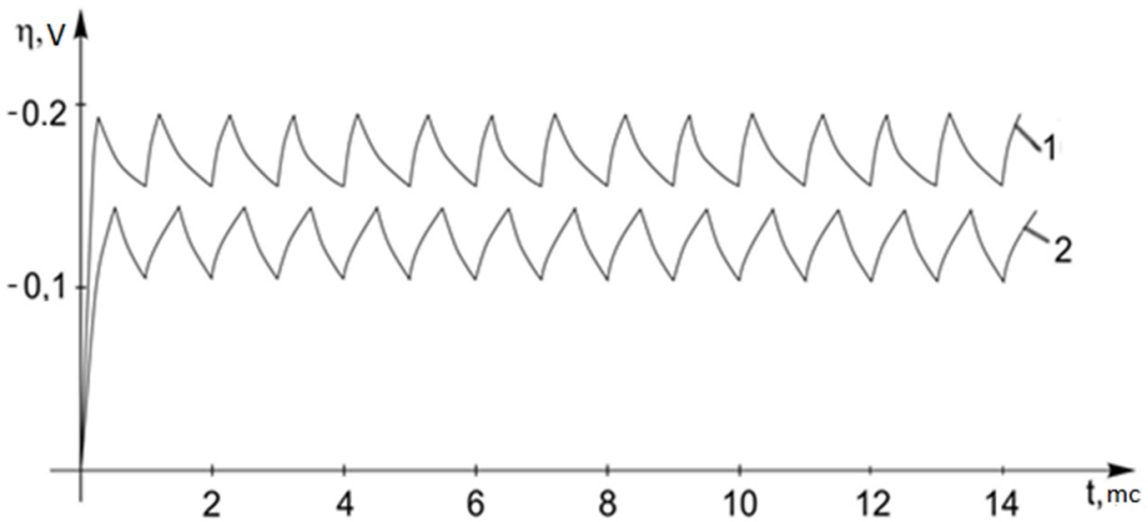

Fig. 3. Overvoltage change on the cathode during the pulse current period:

$$
1-f=1000 \mathrm{~Hz}, \mathrm{Q}=4 ; 2-f=1000 \mathrm{~Hz}, \mathrm{Q}=2 \text {. }
$$

$$
r_{c r}=\frac{2 \sigma V}{z F \eta_{c r}}
$$

where $\sigma$ - surface tension coefficient; V - metal mole volume emitted on the cathode.

The formula does not include the complete overvoltage, but only part of it, connected with the crystallization process, which, according to the authors [6], is the following of the total value:

$$
\eta_{c r} \approx 0,1 \eta_{\text {tot }}
$$

Strongly non-equilibrium crystallization processes leading to the formation of a fine-crystalline structure can also be observed in metallurgy in the quenching process or at ultrafast cooling rates of metals and alloys in a liquid state, with the possibility of formation of metastable states in them. In this case, the size of the critical nucleus formed in the liquid phase depends on the degree of its supercooling [7] as follows:

$$
r_{c r}=\frac{2 \gamma T_{c r}}{L \Delta T}
$$

where $\gamma$ - specific free surface energy; $T_{\mathrm{cr}}$ - equilibrium crystallization temperature; $L-$ latent heat of crystallization per unit volume; $\Delta T$ - melt supercooling degree.

By equating the formulas (2) and (4) and taking into account that $\sigma$ and $\gamma$ are numerically equal to each other, a relationship can be obtained between the crystallization overvoltage on the cathode responsible for the size of critical nuclei, the solid phase being formed, and the melt supercooling degree, at which crystalline nuclei of the same size are formed (5).

$$
\Delta T=\frac{T_{c r} Z F}{L V} \eta_{c r}
$$

Having determined the time interval of the overvoltage rise from the oscillographic curves at the impulse action moment for different deposition conditions, we calculated the melt supercooling rate equivalent to them. The calculations showed that the critical nuclei formed $(9-14 \mathrm{~nm})$ at large cathode overvoltages $(0.4-0.5 \mathrm{~V})$ correspond to the cooling rates $1 \cdot 10^{5}-3 \cdot 10^{5} \mathrm{~K} / \mathrm{s}$. At such cooling rates, in the case of quenching from a liquid or gaseous state, metals and alloys are characterized by a fine-crystalline structure or its complete absence (amorphous state).

According to X-ray diffraction analysis, on a direct current, iron-nickel electrolytes on the cathode form films with an equilibrium, low-defect structure, whose mosaic block sizes are about 250 - $280 \mathrm{~nm}$ [8]. The transition to pulsed current deposition, due to unsteadiness of the processes of nucleation and growth of crystals, led to decreased sizes of the coherent scattering regions (CSR) (Fig. 4).

At frequencies of $1000 \mathrm{~Hz}$ for a duty rate of 2-4, the block sizes were $180-200 \mathrm{~nm}$, which is comparable to the CSR size at a constant current. The increase in supersaturation on the cathode as a result of a decrease in the pulse repetition frequency of unipolar current to 30 $100 \mathrm{~Hz}$ and an increase in the pause between them $(\mathrm{Q}=16-32)$ leads to the increased number of crystallization centers on the cathode surface. The linear growth of the formed nuclei due to the concentration limitations of the ions of the discharging metals and the solution ion depletion in the surrounding crystal zone decreases. This, in turn, leads to the formation of a finecrystalline structure, with decrease in block sizes to 40 $60 \mathrm{~nm}$.

In the framework of the classical theory of nucleation, V.M. Kozlov [9] calculated the work of the formation of two-dimensional nuclei in a normal and incoherent position relative to its own substrate, depending on overvoltage value. According to calculations, it was found that, starting from some overvoltage, exceeding a certain critical one, incoherent nucleation becomes possible. The established relationship between crystallization overvoltage and the subgrain-boundary angle showed that an increase in the

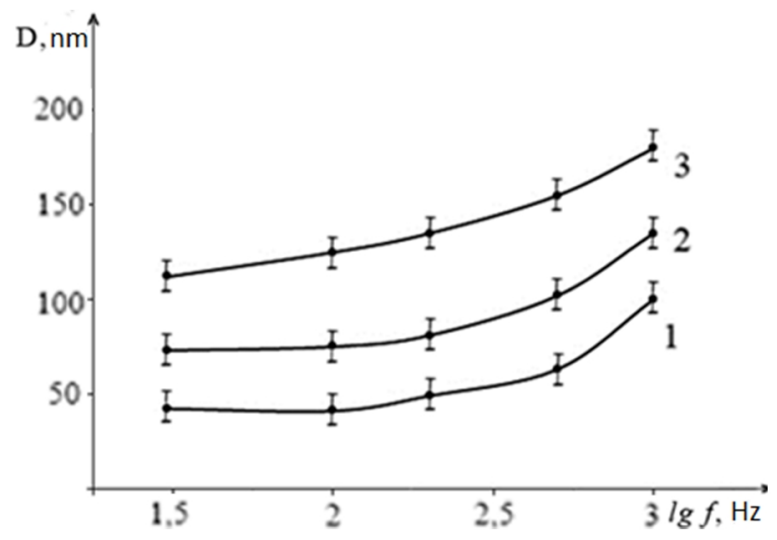

Fig. 4. Dependence of iron-nickel alloy mosaic block size on frequency: $1-\mathrm{Q}=32 ; 2-\mathrm{Q}=16 ; 3-\mathrm{Q}=4$. 


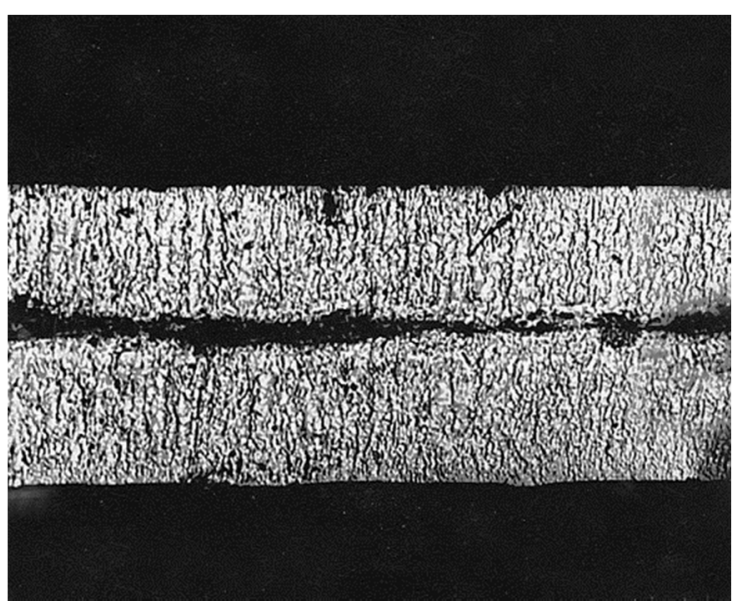

Fig. 5. Structure of iron-nickel alloy in cross section deposited with unipolar current at $1000 \mathrm{~Hz}$ frequency.

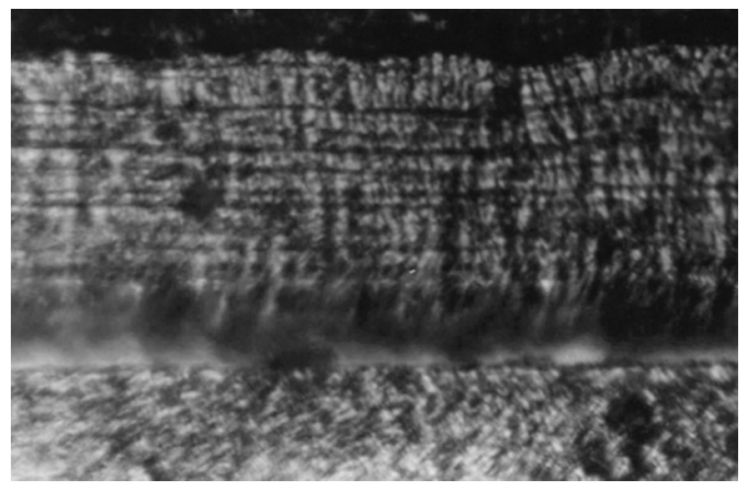

Fig. 6. Structure of iron-nickel alloy in cross section deposited with unipolar current $(f=100 \mathrm{~Hz}, \mathrm{Q}=32)$.

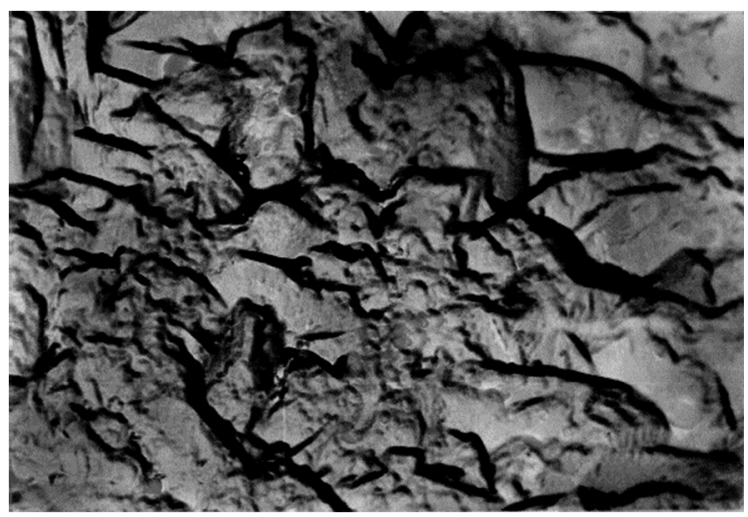

Fig.7. Surface of $\mathrm{Fe}_{42,3} \mathrm{Ni}_{57,7}$ alloy obtained with direct current.

metal deposition overvoltage on the cathode leads to an increase in the boundary angle. In this case, the distance between the dislocations forming the subgrain boundary decreases, which should lead to increase in their density in the crystal. The reason for the appearance of dislocations in some cases is also the difference in the lattice parameters of growing nuclei. In the places where these nuclei grow together, the appearance of defects, in particular, dislocations, plays the role of a compensator for such discrepancies.
To establish the patterns and characteristics of the internal structure of the formed metal films under unsteady nucleation, they were studied using the methods of metallography and electron microscopy. Metallographic studies of the end sections of electrolytic alloys showed that with an increase in supersaturation (cathode polarization) at which the formation of metal films occurs, the nature of their growth changes.

Normal growth (a close-packed face was located normal to the substrate surface) of the nuclei was observed in the coatings obtained at a constant current and at frequencies of $1000 \mathrm{~Hz}$ and more (Fig. 5).

During the transition to the pulsed current deposition, a change in the nature of crystal growth was observed in the film structure. Due to the decrease in the concentration of ions in the cathode region, as well as the occurrence of periodic processes associated with hydrogen evolution and electrolyte alkalization in the cathode region, followed by the formation of hydroxides and their adsorption on the faces of growing crystals, the columnar growth was suppressed and layer-by-layer growth of coatings became dominant (Fig. 6).

The layering of two-dimensional nuclei formed under these conditions produced a multilayer or "package" of growth, the thickness of which depended on the degree of supersaturation. As the development of this multilayer proceeded along the normal, its tangential growth occurred along the cathode surface. As the "package" reached the cathode edge, the formation and growth process was repeated. The thickness of the layers in the coating, with increasing supersaturation, varied

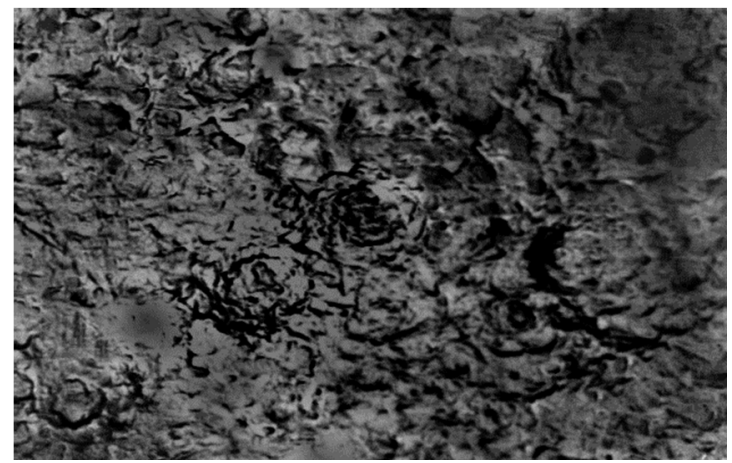

Fig. 8. Surface of $\mathrm{Fe}_{55,9} \mathrm{Ni}_{44,1}$ alloy obtained with pulse current $(f=200 \mathrm{~Hz}, \mathrm{Q}=8)$.

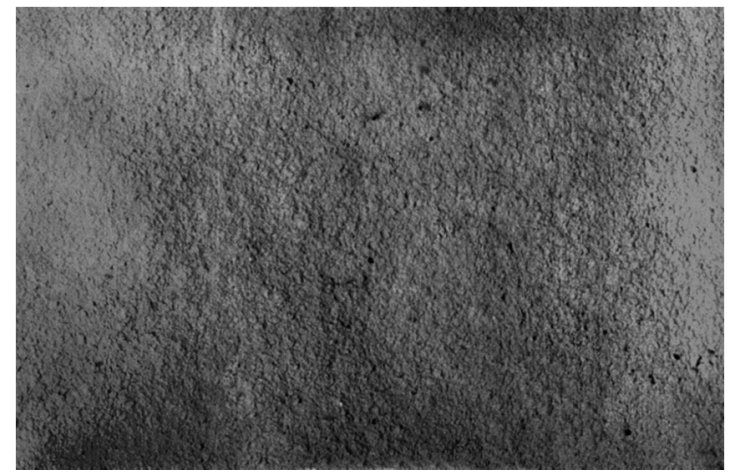

Fig. 9. Surface of $\mathrm{Fe}_{70,3} \mathrm{Ni}_{29,7}$ alloy obtained with the pulsed current $(f=30 \mathrm{~Hz}, \mathrm{Q}=32)$. 
from $0.3-0.6 \mu \mathrm{m}$ to $0.05-0.1 \mu \mathrm{m}$.

The periodicity of growth processes resulted in the formation of crystals consisting of many layered-type sub-grains on the cathode [10]. Electron-microscopic studies of the surface morphology with the help of coal replicas indicate that small polarizations form alloys with a clearly pronounced grain structure (Fig. 7), in which crystallites of relatively regular form are found.

An increase in overvoltage leads to the fact that the size of crystals decreases, their shape changes, and they are fragments of irregular shape with stepwise faces, which indicates their layer-by-layer growth (Fig. 8).

The subsequent increase in overvoltage leads to the fact that the grain fragments are crushed to such an extent that their sizes become commensurate with the size of the mosaic blocks (Fig. 9), the structure is characterized by high dispersion with an implicitly crystalline structure [11].

The study of the substructure of metal films showed that with increasing supersaturation, the dislocation density increases from $10^{8} \mathrm{~cm}^{-2}$ with small overvoltages $(0.05-1 \mathrm{~V})$ to $10^{11} \mathrm{~cm}^{-2}$ in "hard" deposition conditions (0.45-0.55). In coatings obtained on constant and unipolar currents with a frequency of $1000 \mathrm{~Hz}$, we observed the formation of subgranular polygonal-type boundaries, which consisted of edge-dislocation and screw-dislocation network forming torsion boundaries, the fragment-boundary inside the grain did not exceed $1^{\circ}$ - $2^{\circ}$. Within the fragments, microtwins and packaging defects were relatively rare. The bulk of structural imperfections was concentrated in interblock and intergranular regions.

\section{Conclusions}

1 The non-equilibrium crystallization processes occurring during non-stationary electrolysis, and the magnitudes and rates of change of supersaturation on the cathode created by them at the time of the current impulse, in their effect on the alloy structure are equivalent to the supercooling rates that occur during metal quenching.

2. While increasing the supersaturation degree at the crystallization front, the cathode coating growth mechanism changes from normal to tangential one.

Ganich R.P. - Senior Lecturer of the Department of Physics;

Zabludovsky V.O. - Professor, Doctor of Technical Sciences, Professor of the Department of Physics;

Artemchuk $\boldsymbol{V} . \boldsymbol{V}$. - Doctor of technical sciences, associate professor, professor of chair of electromotive warehouse.

[1] V.A. Zabludovsky, E.F. Shtapenko, V.S. Gribok, R.F.Ganich, A.N. Gulivets, M.V. Gadzhilov, Vliyaniye skorosti peresyshcheniya na formirovaniye struktury elektroosazhdonnykh plonok [Effect of supersaturation rate on the formation of the structure of electrodeposited films]. Proceedings of the IX National Conference on Crystal Growth NKRK - 2000, December 16-20, 2000 (Moscow, IC RAS). P. 505.

[2] I.V. Sally, Kristallizatsiya pri sverkhbol'shikh skorostyakh okhlazhdeniya [Crystallization at very high cooling rates] (Naukova Dumka, Kiev, 1970).

[3] A.V. Osipov, Physics and Chemistry of Materials Processing 5, 71 (1991).

[4] K. Vetter, Electrochemical kinetics; trans. from German by Y.M. Kolotyrkin (Chemistry, Moscow, 1967).

[5] N.A. Kostin, V.S. Kublanovskyi, V.A. Zabludovsky, Impul'snyy elektroliz [Pulse electrolysis] (Naukova Dumka, Kyiv, 1989).

[6] V.V. Trofimenko, Yu.M. Loshkaryov, V.S. Kovalenko, Proceedings of the Academy of Sciences of the USSR 277(5), 1181 (1976).

[7] U. Weinhardt; trans. from English by O.V. Abramova, Introduction to the physics of metal crystallization (Mir, Moscow, 1967).

[8] V.A. Zabludovsky, R.F.Ganich, A.D. Zabludovskaya, Vìsnik Dnìpropetrovs'kogo unìversitetu. Serîâ Fìzika, radìoelektronika 6, 22 (2000).

[9] V.M. Kozlov, Electrochemistry 17(9), 1319 (1981).

[10] V.V. Povetkin, I.M. Kovenskyi, Metals 2, 108 (1982).

[11] R.P.Ganich, V.O. Zabludovsky, V.V. Artemchuk, Struktura yelektrolítichnikh splavív Fe-Ni otrimanikh ímpul'snim strumom [Structure of electrolytic Fe-Ni alloys obtained by using pulse current]. Abstracts of the $76^{\text {th }}$ International Practical Scientific Conference "Problems and Prospects of Railway Transport Development" 19-20 May 2016 (Dnipropetrovsk, 2016). P.75. 


\section{Р.П. Ганич, В.О. Заблудовський, В.В. Артемчук}

\section{Структура залізо-нікелевих покриттів, отриманих імпульсним струмом}

Дніпровський національний університет залізничного транспорту, ім. акад. В. Лазаряна, вул. Акад. В. Лазаряна, 249010 Дніпро, Україна, art vv@ukr.net

Представлені результати дослідження структури плівок залізо-нікелевого сплаву, отримані на імпульсному уніполярному струмі 3 розчину електроліту. Показано, що в умовах нестаціонарної електрокристалізації на катоді протікають процеси, які призводять до формування сильно нерівноважних структур і зміни характеру росту покриття зі стовбчастого на пошарове.

Ключові слова: нестаціонарний електроліз, катодне перенапруження, пошарове зростання, щільність дислокацій, блоки мозаїки. 